\title{
A Challenge to Business Leaders to End Earnings Management
}

\author{
Jason Eugene Call \\ University of Wisconsin - La Crosse
}

It is time for users of corporate financial statements to demand an end to abusive earnings management (EM). EM has persisted for decades as Accrual-based and Real EM. Both flourish inside vague accounting principles and under the veil of corporate secrecy. The existence of EM is irrefutable; it is well-documented in professional and academic literature. What is missing from the literature are simple, commonsense strategies for eliminating EM or rendering it harmless. EM is bad for our financial system for many reasons. When business leaders abandon EM or use it sparingly, financial reporting will increase in quality.

Keywords: Earnings Management, Financial Analysts, Ethics, Earnings Quality, Business Leaders.

\section{INTRODUCTION}

Earnings Management (EM) has been a problem for stakeholders in public companies for decades (Healy, 1985). EM occurs when company insiders use their knowledge of complicated accounting rules and ability to time business transactions to manage earnings either up or down in the short term. Markets tend to reward companies that meet or beat consensus earnings targets; companies that miss earnings targets are punished. Company insiders can personally benefit from EM. However, they have a fiduciary duty to maximize the long-term value of all the company's stakeholders in accordance with corporate strategy and corporate social responsibility. Earnings and profits are good, and executives are right to maximize them. They should be rewarded for creating and sustaining value for all stakeholders. However, if the earnings are the result of short-term schemes that benefit some stakeholders in one period while hurting other stakeholders in the future, the earnings are illusory. When abused, EM robs from the future to pay current benefits. 
TABLE 1

EM WITH A HAPPY ENDING

\begin{tabular}{|c|c|c|c|c|c|c|c|c|c|c|c|c|c|}
\hline & \multicolumn{5}{|c|}{ Second Quarter } & \multicolumn{4}{|c|}{ Third Quarter } & \multicolumn{4}{|c|}{ Fourth Quarter } \\
\hline & Actual & Old & EM & Up EM & Managed & Actual & Old EM L & Down EM & Managed & Actual & Old EM & EM & Expected \\
\hline Revenues & $\$ 4,500.00$ & $S$ & - & $\$ 22.50$ & $\$ 4,522.50$ & $\$ 4,635.00$ & $\$(22.50)$ & $(4.64)$ & S 4,607.87 & & S 4.64 & & \\
\hline Expenses & $3,900.00$ & 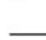 & - & (19.50) & $3,880.50$ & $\underline{\$ 3,939.00}$ & 19.50 & 3.94 & S $3,962.44$ & & (3.94) & CEO \& & \\
\hline Earnings & 600.00 & & - & 42.00 & 642.00 & S 696.00 & $(42.00)$ & $(8.57)$ & 645.43 & & 8.57 & $\begin{array}{l}\text { CFO } \\
\text { Only! }\end{array}$ & \\
\hline WA Basic & 600.00 & & - & & 600.00 & S 600.00 & & & 600.00 & & & & \\
\hline EPS & 1.00 & s & - & & 1.07 & S 1.16000 & & & 1.08 & & & & \\
\hline
\end{tabular}

TABLE 2

EM WITH AN UNHAPPY ENDING

\begin{tabular}{|c|c|c|c|c|c|c|c|c|c|c|c|c|}
\hline & \multicolumn{4}{|c|}{ Second Quarer } & \multicolumn{4}{|c|}{ Third Quarter } & \multicolumn{4}{|c|}{ Fourth Quarter } \\
\hline & Acrual & OUEM & Up EMI & Managed & Acrual & OXS EM & $U_{p} E M$ & Managed & Acrua! & OIAEM & EM? & Expected \\
\hline Revenues & $\$ 4,500.00$ & $s-$ & $\$ 22.50$ & $\$ 4,522.50$ & $\$ 4,477.50$ & $\$(22.50)$ & 89.55 & $\$ 4,544.55$ & $\$ 4,522.28$ & $\$(89.55)$ & $s-$ & $\$ 4,432.73$ \\
\hline Expenses & 3900.00 & - & $(19.50)$ & 3.880 .50 & $\$ 3939.00$ & 19.50 & $(59.09)$ & $\$ 3.899 .42$ & 3958.70 & 59.09 & - & 4.017 .78 \\
\hline Eaming & 600.00 & - & 42.00 & 642.00 & S 538.50 & $(42 . \infty)$ & 148.64 & 645.14 & 563.58 & $(148.64)$ & - & 414.95 \\
\hline WA Basi: & 600.00 & - & & 600.00 & s 600.00 & & & 600.00 & 600.00 & & & 600.00 \\
\hline EPS & 1.00 & - & & 1.07 & 0.90 & & & 1.08 & 0.94 & & & 0.94 \\
\hline
\end{tabular}

Corporate leaders, lenders, financial analysts (FAs), regulators, and auditors all know about and understand EM. It lurks within complicated accruals, biased estimates, and ambiguous accounting principles (Capkun, Collins, \& Jeanjean, 2016) and is protected by corporate secrecy. Clever use of EM is rewarded by markets and will enrich its masters. However, when earnings are managed, the truth is obscured and confidence in financial information is eroded. If a company is a going concern, most stakeholders will favor a long-term approach over a short-term one. Short-term decisions and abrupt changes in accounting principles can hurt long-term investors. However, not every stakeholder is long; if a stakeholder is in a short position EM might protect them. Feres de Almeida, Neto, Furieri Bastianello, and Zandomenigue Moneque (2012) revealed one possible benefit of income smoothing; smoothing through EM makes business leaders less likely to take a sudden, aggressive write-down that would harm short-term stakeholders. Since markets can overreact to negative surprises, business leaders can unfairly harm some investors that find out about a corporate loss too late to hedge their position.

Signaling accounting information to the public may mitigate stakeholder losses, but it can be risky because company leaders possess valuable inside information. They must be careful to disclose information properly. Disclosure and transparency can reduce the signaling costs. Otherwise, clumsy use of smoothing can prepare markets to expect good news or bad news (Jiang, \& Yang, 2016). On the one hand, investors might view an aggressively conservative estimate or accrual favorably, especially those in a long position. On the other hand, too much upward EM might send a signal that company leaders are struggling to find a successful and sustainable business strategy; the EM is delaying the eventual demise. EM distorts reality.

EM dilutes the quality of earnings reports and creates inefficiency in the market due to information asymmetry. There will always be some information asymmetry in order to protect company proprietary information and marketing strategy. However, EM makes it difficult for people to trust financial information and make sound investment decisions. Not all EM is equal, some company leaders use EM wisely and sparingly. Others can go too far. If company leaders make the right call, EM may never be 
noticed. However, if company leaders engage in EM for too long, they may be forced to violate Generally Accepted Accounting Principles (GAAP) to cover up a misstated balance sheet (Ettredge, Scholz, Smith, \& Sun, 2010). For example, if a company needs just a penny to meet earnings expectations, that one comes cheap. Company leaders only need between $\$ 0.00001$ and $\$ 0.005$ to round up the EPS one cent. Second, third, and subsequent pennies come at the full price.

\section{FIGURE 1 \\ THE SOCIALLY OPTIMAL LEVEL OF EM}

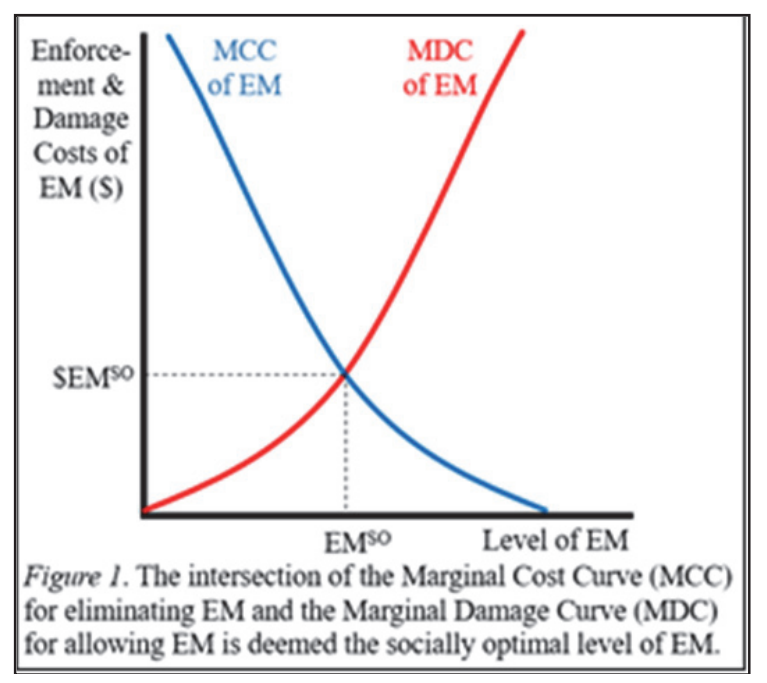

Why has no one done anything substantial to eliminate EM or make it harmless to stakeholders? Have business leaders, investors, lenders, and regulators become comfortable with the present cost-benefit paradigm and decided there is no reason to disrupt the status quo? If so, our financial system has reached a situation with respect to EM known as the socially optimal level of an externality (Anderson, 2015). Perhaps the perpetual problem of EM is that no one has suggested an end to the practice. Maybe that time is now.

The author of this paper will discuss the problem of EM in the business world. EM is a significant problem in financial markets. This assertion rests upon a vast foundation of professional and academic literature on the subject. The author encourages a more robust scientific study of EM by more experienced and qualified academics and scholars.

EM is a major problem, but there are simple, common sense solutions. Because EM is so entrenched in the business community, all stakeholders that rely on accurate financial reporting need to support its elimination. Apart from the literature review, the author of this paper acknowledges most of the assertions are only based on opinion; specific examples and candid discussion of EM are difficult to obtain. Talking openly about EM is too dangerous for business leaders because they might expose themselves to legal jeopardy from disgruntled outside stakeholders and skeptical regulators. EM is a problem, but there are solutions.

\section{The Significance of the Study of EM}

This study of EM is significant because EM is a common business problem. EM erodes the quality of financial information and undermines trust in reporting. Investors should be able to rely on financial statements. When EM is used, company insiders can reap huge personal benefits at the expense of outsiders. Outside stakeholders are entitled to know the details of important accounting policies (FASB, 2018a). EM creates information asymmetry; it prevents company outsiders from making informed financial decisions based on sufficient information. EM can deceive stakeholders; it can violate GAAP requirements to disclose the use of atypical and creative methods of revenue recognition and accruals 
(FASB, 2018b). Surreptitious use of EM makes financial analysis more difficult for investors and forces auditors to increase testing and fees. If business leaders use EM well, they can enrich themselves at the expense of other stakeholders. If they do not use EM well, they can cause huge losses for unwary investors when their financial shenanigans are exposed.

\section{FIGURE 2 THE EM EXTERNALITY}

Costs of
Financial
Infor-
mation
(S)
Figure 2. EM increases the cost and erodes the quality of
financial information for all stakeholders in subtle, but
incalculable ways. The negative externality of EM costs
include: Audit fees, agency costs, regulation and enforcement
costs, and stakeholder losses.

Not all the costs of EM are external. Nketia (2019) explored the use of EM in private firms. Even though non-listed companies do not have to conform to GAAP and issue audited financial statements, research shows that they can engage in EM after incurring debt. Business leaders will incur the expense of learning about and employing EM because those costs are outweighed by the draconian consequences of violating a debt covenant or other contractual agreement. However, EM is not used to the same extent when original or new debt is being acquired. This may be because the perceived costs of EM are not exceeded by lower borrow rates from EM-enhanced financial statements. This research is very interesting because it might establish an estimate of cost-considerations and thresholds that business leaders use before they engage in EM. Business leaders know that EM is risky; in the extreme, EM use is a moral hazard.

The people who use EM keep the information close; they are careful with whom they discuss the matter with and avoid documentation. This is known as information asymmetry and can constitute a violation of fiduciary duty. If everyone knew about the EM because company leaders disclosed it and detailed their EM policy in their reports, there would be no problem. However, without any rules, policies, or controls, few company leaders would admit to using EM because of the potential for huge civil and criminal liabilities. If business leaders cannot speak openly about something they are indeed doing with other peoples' assets, perhaps it is wrong. EM can appear benign and clever use can remain undetected. Unfortunately, business leaders can go too far. At its worst, EM can devolve into outright fraud, lead to restatements of financial reports (Ettredge et al., 2010), financial scandals, company bankruptcy, and huge stakeholder losses. 


\section{A Review of the Professional and Academic Literature}

EM is a common problem for publicly listed companies. The practice is well documented in the business world; from 2007-2017, an average of over 140 articles on EM appeared each year in scholarly journals (Mindak, Sen, \& Stephan, 2016; Vladu, 2015). EM comes in two forms. Accrual-based EM (AEM) exploits complexity and vagueness in accounting rules to either increase or decrease revenue (Filzen, \& Peterson, 2015; Greiner, Kohlbeck, \& Smith, 2017). Capkun et al. (2016) showed that some companies exploited the transition period for adopting International Financial Reporting Standards (IFRS) to engage in EM. Evans, Houston, Peters, and Pratt (2015) suggest that principles-based IFRS is more conducive to AEM. AEM often involves management estimates and manual journal entries; it leaves evidence in the accounting system. For example, overly optimistic or conservative estimates and accruals will likely attract attention. A recently discovered method of AEM by retailers is creativity in estimating gift card breakage, or lost or unredeemed gift cards (Kaufinger, 2015). Aggressive or conservative estimates can boost earnings now or roll them forward, respectively. Whenever management makes estimates that can create an opportunity for both upward and downward EM. There should always be substantial evidence to support their calculations and estimates if they are material. Auditors understand AEM is a potential problem in estimates and accruals; they have developed strong analytical tools to detect the practice.

Real EM (REM) is more difficult to detect because only its perpetrators know the true story. REM involves altering the scope and timing of legal business transactions. GAAP does not prohibit REM (Greiner et al., 2017; Evan et al., 2015). For example, if business leaders cut back on expenses or accelerate revenues for strategic reasons, it is not REM. EM is the means to obtain short-term ends for some people. If business leaders cut back on expenses in one period to boost earnings and then increase the same expenses in the following period, it is probably REM; there is no economic reason for it.

One expense that is an easy victim of REM is research and development (R\&D). Investing in R\&D can lead to innovation and valuable discoveries. Along with acquisitions, it can be of strategic importance for many companies striving to obtain or maintain a competitive advantage in the marketplace. However, if the choice for executives is between meeting an important sales or earnings target or maintaining R\&D spending, often R\&D will suffer (Grabińska, \& Grabiński, 2017; Fang, \& Fu, 2018). This seems like an easy choice because the financial payoff for $R \& D$ is in the future and, if reduced, the cost savings can boost earnings in the current reporting period. An exception to the common pillaging of R\&D for REM may be innovative-intensive companies, those identified by registering new patents. Hu (2019) argues that if EM is deemed necessary by the leaders of such companies, they will likely maintain R\&D and opt for AEM, instead. Marketing expenses are often cut for REM, even though it can hurt sales and brand image over time. Because sales and expenses can be related, REM can often have a detrimental impact on future periods and harm stakeholder value.

Revenues can be shifted between reporting periods. If a company loosened credit standards with customers or offered temporary discounts, sales would likely increase in the short-term. This change in policy would boost earnings in the quarter of the change (Collins, Pungaliya, \& Vijh, 2017). However, if credit standards are set too low or discounts set too high, the increased bad debt expenses in the future and decreased sales from customers' over-purchasing would result in lower earnings in other periods. EM often takes from the future to create a benefit the present (Medeiros Cupertino, Lopo Martinez, \& da Costa Jr., 2016).

EM makes a business look better to investors, but that image is artificial. Business leaders often engage in EM prior to selling new equities or borrowing (Cohen, \& Zarowin, 2010; Mellado-Cid, Jory, \& Ngo, 2017). Another opportunity for EM is to boost the stock price right before an executive's stock options vest (Cheng, Lee, \& Shevlin, 2016) or at year-end to increase a performance bonus. Company leaders can tinker with the estimated tax expense and related accruals the end of the year to manage earnings if needed at the very last moment (Dhaliwal, Gleason, \& Mills, 2004). REM usually focuses on the short-term; this rewards some stakeholders at the expense of others. REM is subtle and can be difficult to expose. 
EM can be either positive or negative, or both. In the case of negative EM, business leaders can store earnings in profitable periods for use in unprofitable periods (Naidu, \& Patel, 2013). Sometimes a company has a great quarter or year. For example, leaders can store earnings for later by over-estimating the taxes payable or increasing the allowance for doubtful accounts (Dhaliwal et al., 2004; Trejo-Pech, Weldon, \& Gunderson, 2015). When they need some earnings to meet a target in the future, they can conveniently discover the previous over-estimates and conservative accruals will eventually reverse in the future (Legoria, Melendrez, \& Reynolds, 2013). In the case of allowance for doubtful accounts or warranty liabilities, an overestimate will mean not having to recognize as much expense in future periods; this will make earnings larger than they would have been. Storing earnings for later is referred to as the accounting cookie jar (Ekimoff, 2014, Caylor, \& Chambers, 2015).

It takes professional judgment and skepticism to determine whether a business decision is legitimate or constitutes REM. Auditors worry about REM because it can signal a poor ethical tone in the executive suite (Commerford, Hermanson, Houston, \& Peters, 2016). The frequent use of AEM and REM can indicate a proclivity for fraud by company leaders. Often, when companies are forced to restate earnings, there is ample evidence of EM in prior periods (Ettredge et al., 2010). Both AEM and REM can be used to manage earnings across accounting periods (Vladu, 2015), either together or individually. EM is also known as smoothing (Ekimoff, 2014).

EM results from the agent-principle problem (Palliam, \& Shalhoub, 2003); EM should be viewed through the lens of agency theory (Bendickson, Muldoon, Liguori, \& Davis, 2016; Paiva, Lourenço, \& Branco, 2016; Pepper, \& Gore, 2015). Business leaders can use EM to advance their short-term interests at the cost of principals' long-term interests. Both AEM and REM can create moral hazard and adverse selection dangers. EM, particularly REM, is very difficult to detect because only insiders know for certain it is being used. Otherwise, it might just appear to be savvy business acumen. Agency costs to prevent reckless EM, such as monitoring and internal controls, can be expensive (Chandren, 2016); principals should keep an eye on their agents or suffer the consequences. Often, qualitative methods are required to detect REM (Legoria et al., 2013; Antwi, \& Hamza, 2015). REM thrives due to information asymmetry, vagueness, and ambiguity; all these issues stem from agency problems.

EM also causes signaling problems in the market (Jiang, \& Yang 2016) because the practice conceals correct information and reveals incorrect information. Not only are investors mislead by EM. If business leaders make clever use of EM, they can sabotage the decision-making at competing firms. Li (2016) shows that when leaders in firms misperceive a rival's good financial performance, they can over-invest in assets and acquisitions in a desperate attempt to remain competitive. Other unwise decisions can include over-spending on R\&D and marketing, reducing prices unnecessarily, and over-cutting other expenses. Unfortunately, business leaders mislead by their rivals' clandestine use of EM are chasing a very expensive illusion. EM can create waste and inefficiency in the marketplace, to the detriment of society.

People experienced in finance and corporate reporting can detect even subtle EM. For example, if earnings quality is considered high, then outsiders rely on the income statement to predict future earnings; if earnings quality is low, then they rely on cash flows instead (Al-Attar, Maali, 2017). In the latter case, markets stop trusting the GAAP income statement because of AEM. Experienced financial analysts and other savvy outside stakeholders can adjust earnings expectations and pricing to negate the effects of EM. However, unwary stakeholders are likely to be harmed due to information asymmetry and signaling misconceptions. Too much EM can render accrual-based financial statements useless; a false balance [sheet] is an abomination (Proverbs 11.1) and undermines the efficient allocation of capital. Abusive EM can cause great harm to society.

Markets tend to reward upward EM (Mindak et al., 2016); when a company meets or beats earnings expectations it's stock price usually increases. The downside of EM is that it favors short-term gains at the expense of long-term value. The boost in the stock price is unjustified and temporary. If managers view EM as insufficient to prevent a shock, they can engage in expectations management; they can release negative information to cause FAs to lower earnings expectations (Zhu Liu, 2014). For example, business leaders can file an $8 \mathrm{~K}$ to report monthly sales to show declines. They can also leak information 
to the public that earnings are down for a period, but this might violate rules. This practice will mitigate the negative market reaction to poor earnings. Markets dislike EM; it weakens earnings quality and increases uncertainty and risk.

Sometimes the qualitative side of financial reporting is more important than the numbers. For example, the Management Discussion and Analysis (MD\&A) portion of the annual report is studied closely. Press releases and earnings conference calls also provide valuable information and signaling to company outsiders. Xuan, Siew Hong, \& Yinglei (2014) studied the words used by company leaders in public disclosures and found that an abnormally positive tone was indicative of future poor performance. Investors should be wary of excessively positive language; ordinary language carries more credibility (Zhu Liu, 2014). Lo, Ramos, and Rago (2016) show a positive relationship between complexity and unreadability of the MD\&A section and EM. If it is too wordy or cryptic, that section of the annual report might be indicative of EM. This finding supports the notion that good information is easier to convey than bad information (Hancock, Curry, Goorha, \& Woodworth, 2008). The truth is easy because it is founded in fact, obfuscation has no basis in facts and must be created. Any public release by business leaders can provide clues of EM and stakeholders should be wary.

Few companies win all the time. When a company has a bad quarter or year, leaders can take the opportunity to clean up all the problems with the balance sheet in one fell swoop. They can recognize all impairments and write-downs. This tactic is a form of EM known as the big bath (Jordan, \& Clark, 2015; Trejo-Pech et al., 2015). An ideal opportunity for an EM big bath is when a new CEO arrives at the company. A new CEO prefers to start her tenure with a loss for several reasons, such as the market tends to punish the company the same way whether there is a big loss or small loss, getting rid of unproductive assets will boost future ROA and ROE, and starting with a loss will make any future good performance look even better (Jordan, \& Clark, 2015). A big bath is an opportunity for company leaders to get some small benefit from an otherwise bad reporting period.

EM is a business problem because business leaders can use it to achieve higher than normal earnings to meet expectations (Evans et al., 2015). FAs are professionals that work for firms or institutional investors to monitor the performance of companies (Zhu Liu, 2014); FAs often set quarterly sales and earnings expectations for the companies they monitor (Fedyk, 2017; Mindak et al., 2016). Those earnings announcements and the company's respective miss, meet, or beat announcements are all closely watched by investors. FAs rely on company information; they can be victims of EM like everyone else. Not every publicly-traded company has a dedicated FA, but a large corporation may have several FAs monitoring its performance at all times. FAs know a lot about the companies they monitor and the industry, but they are still outsiders. People in the financial and accounting industry do not all agree on the merits of the FA.

On the one hand, many people believe that the FA provides an invaluable service to stakeholders. FAs are often the ones to ask tough questions of managers, demand accurate financial reporting, explain complicated business transactions, and expose accounting fraud (Zhu Liu, 2014). With one or more FAs snooping around, the presumption is that company managers will be more honest and transparent; they will avoid aggressive and creative accounting and will avoid decisions that favor short-term goals. Research supports this view. Company leaders know they will have to face FA questions at every quarterly earnings conference call. EM is negatively related to FA and institutional investor coverage (Zhu Liu, 2014). More proof of FA value is the fact that capital markets rely on their opinions heavily (Fedyk, 2017). Business leaders also acknowledge the value of FA earnings expectations; they understand that failure to meet or beat the FA targets will result in a negative market reaction (Mindak et al., 2016). Many business leaders view the FA expectations as their most important benchmark of success (Zhu Liu, 2014). Indeed, there is much evidence that the FA plays an important role in the business world.

On the other hand, some people in the financial industry feel that the FA can create more problems than benefits. Research shows that FAs are influenced by many factors, like company size and EM motivations (Qian, Gaixia, Jiayi, \& Qun, 2017). FAs and can be biased and overreact to favorable company news and underreact to unfavorable company news (Caylor, Christensen, Johnson, \& Lopez, 2015); FAs also cling to their errors for an average of three quarters before abandoning them (Fedyk, 2017). It is hard to admit when you are wrong. FAs can lack the experience, skills, and independence to 
act as effective monitors. For example, a FA can fail to spot an aggressive, complicated accrual that must reverse in the future or might have too many financial ties with a company to be objective (Zhu Liu, 2014). If a FA sets earnings targets too high, company leaders can respond with aggressive upward EM (Caylor, 2010). If a FA sets earning targets too low, company leaders can use conservative accounting principles in GAAP to stash some earnings away for future use in the cookie jar. Although revenuedecreasing EM is not rewarded by the market, it is made possible by FA underestimate errors (Mindak et al., 2016). In some ways, FAs can contribute to the EM problem by setting earnings targets, but only company leaders can manage earnings and only they know for sure if a decision is EM.

Scholarly research yields some interesting results that confirm EM. In China, EM shows an inverted $\mathrm{U}$ shape when compared to CEO tenure. The $\mathrm{Hu}$ "U" can help regulators and analysts to anticipate increasing EM by executives, as they consolidate their power base in the executive suite and their compensation packages begin to vest (Hu, Hao, Liu, \& Yao, 2015). After they maximize the benefits from EM, executives begin to see too many risks and decrease EM use. Other relationships between EM and CEO's are more intuitive. Research shows that draconian government regulations, cost-leader marketing strategies, CEO reputation and popularity, and CFO gender have a clear and direct relationship to EM (Li, Luo, \& Ng, 2014; Liu, Wei, \& Xie, 2016; Peng, Lei, \& Tingting, 2015; Peng, Lei, \& Xiao, 2016; Welker, Ye, \& Zhang, 2017). Governments and markets should be careful not to force companies to choose between EM and survival. Gender is also important. Not only is it the right thing to do but making the executive suite more gender-balanced will help to eliminate EM. Cohen, Ding, Lesage, and Stolowy (2017) show that despite sensational media coverage of fraud cases, flamboyant executive lifestyle and personality cannot easily predict a tendency for unethical behavior.

\section{FIGURE 3}

\section{CEO TENURE AND EM}

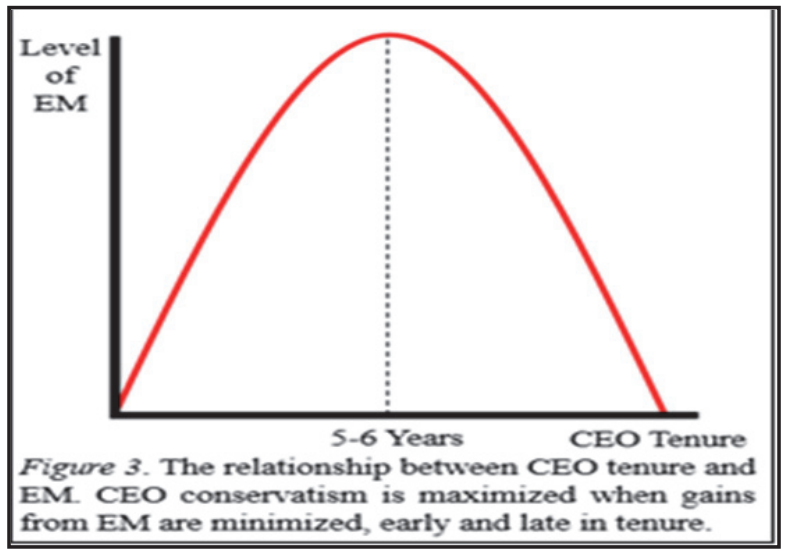

Of course, some issues have an inverse relationship to EM. Such anti-EM factors are strong executive subordinates, strong and large Boards, and FA coverage (Cheng, Lee, \& Shevlin, 2016; Yasser, \& Al Mamun, 2016; Qaiser, \& Abdullah, 2016; Zhu Liu, 2014). Untenured executives are more likely to take a dim view of short-sighted EM and oppose the strategy. They are long on the company and do not want to take reckless actions that might hurt the company and get them fired. Also, when a lot of powerful and knowledgeable people are watching business leaders, EM is made much more difficult. Research shows that CEO's with accounting backgrounds are less conservative than others; however, the evidence does not indicate that an accounting background leads to more upward EM (Hu, Huang, Li, \& Liu, 2017). The fact that some factors can either increase or decrease EM proves the pervasive existence of EM. There is no way to ignore the preponderance of the evidence that EM is a factor in publicly listed companies. 


\section{FIGURE 4}

\section{FACTORS THAT INCREASE EM}

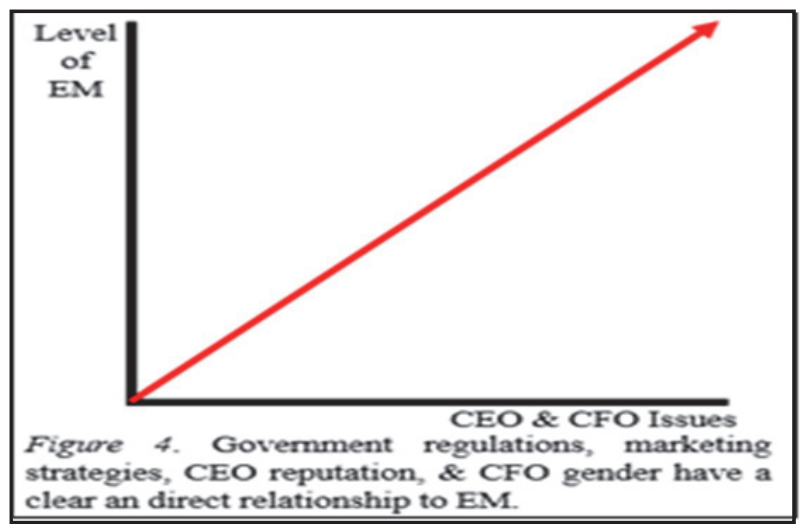

\section{Strategies for Eliminating EM}

Business leaders and managers focus on earnings - and they should. Principals hire them to use their talents, insights, and leadership to employ the organization's assets in the most efficient manner to produce the greatest long-term benefits consistent with corporate strategy and corporate responsibility. However, managers can focus on short-term benefits, particularly if there is excessive pressure to deliver results or if compensation is too dependent on aggressive targets. Strong corporate governance is required to eliminate EM. The directors of the corporation should structure executive compensation so that it does not reward reckless tactics to achieve short-term goals or discourage a prudent, long-term value strategy (Pepper, \& Gore, 2015). If leaders are too risk-averse, that can lead to company failure, too. Managers should earn rewards for producing sustainable earnings and increasing stakeholder value.

\section{FIGURE 5 \\ FACTORS THAT DECREASE EM}

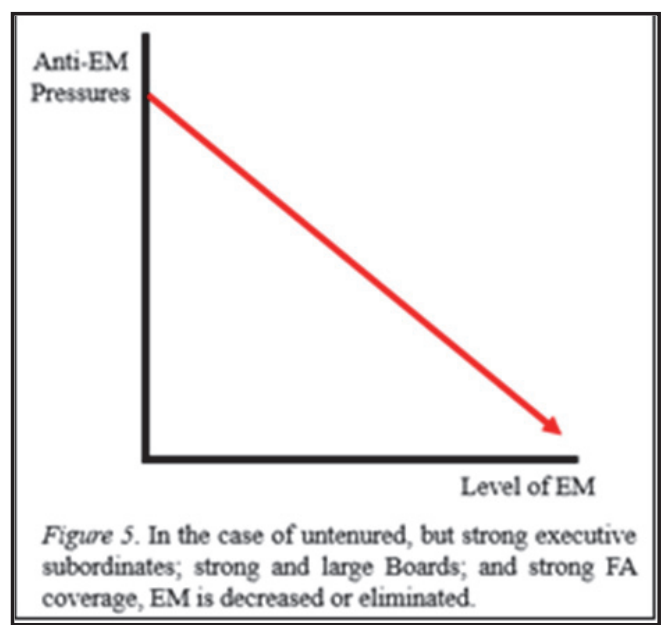

It is not difficult for a corporation to develop and adopt a no-EM policy and to enforce it. Making sure that executives are challenged with reasonable targets is a good first step. Unreasonable targets often lead to EM, or worse. EM exists because it has been rewarded by the markets and has enriched company insiders that have successfully employed it. If the rewards stop, so will EM. If EM is eliminated or tamed, earnings quality will increase and that will be rewarded by markets. Investors will indeed pay a premium for high-quality financial reporting (Kamarudina, \& Ismailb, 2014). Of course, high-quality reporting 
means that the ups and downs smoothed out through EM will be exposed. Stock prices could suffer in the short-term until markets adjust to and accept the un-managed financial statements.

Companies that eliminate EM will have a competitive advantage over those that hold on to the old EM habits; those companies will be known for low earnings quality and suffer for it. Akisik and Gal (2017) show that customers will favor companies with strong internal controls and strong corporate social responsibility. Who would pay a premium stock price for an EM-using company and its low-quality earnings? In the following section, the author presents several strategies for business leaders to eliminate EM or render is harmless.

\section{Just One Simple Question}

Executives make plans. When an executive in considering deviating from the plan, she should ask herself, "how is this change not EM?" It is a simple question and documenting the answer should not be difficult. If something is EM it will involve a short-term issue and may benefit the decision-maker or only a few other well-connected stakeholders. A prudent business decision will benefit all the stakeholders and conform to corporate strategy and corporate responsibility. No company includes in its mission statement that its leaders will do whatever it takes to meet or beat arbitrary earnings targets announced by a FA or Wall Street, and yet many executives behave like that is the real mission. If company leaders alter accounting policies immediately before or after the announcement of EPS targets, it is probably EM (Caylor, 2010). A good corporate leader will inspire managers to do the right thing; in turn, good managers will to the right thing in the best way. Reckless EM is never the right thing. Eliminating EM can be quite simple.

\section{Using the Budget to Eliminating EM}

Budgets are almost universally used by managers to plan and control operations (Cardos, 2014; Radu, \& Giju, 2015). Technology and communication improvements now allow managers to monitor differences between actual activity and budgeted activity in real or near-real time. Positive and negative variations in the budget, if material, demand investigation. Managers can then adjust operations to return to the budget. If the budget is defective, the budget can be changed. This is what managers do to achieve company goals and objectives. Deviating from the budget is not EM unless doing so is meant to achieve a short-term benefit that will reverse in a future period. Budgets are an important tool for managers to eliminate EM.

For example, if budgeted spending on marketing was reduced in one quarter and then increased over the budget in the following quarter, this would appear to be a classic example of EM. The marketing budget is prepared in advance. Presumably, if the marketing return on investment (MRI) was greater than one, every dollar spent on marketing would more than pay for itself in additional sales generated. Marketing is integrated with the company strategy. Shifting a budgeted expense from one period to the next boosts earnings in one period at the expense of another. It simply reverses in the next period.

Currim, Lim, and Zhang (2018) studied firms under FA earnings pressure; those firms were likely to reduce marketing expenses. They also showed that firms that resisted FA pressure and maintained marketing expenditures performed better over the long term. EM is a win-lose situation or a zero-sum game. Now consider the same scenario, except there is an economic benefit to the change in spending. If moving the marketing expense to the next period resulted in much lower rates for advertising or more effective media coverage for the same cost, it would be a long-term benefit to the company. It would be a win-win; there would be more earnings now and more earnings later. Managers should take advantage of every opportunity to increase earnings in a sustainable way. This is their fiduciary duty to principals.

Ultimately, EM is inconsistency founded in a desire to achieve an immediate need. Of course, managers cannot let a budget prevent them from adapting to changing business circumstances and opportunities. They should deviate from the budget when it makes sense to do so; deviating from the budget to achieve s short-term goal that will undermine future performance is not a good reason. Managers know why they make decisions; a person cannot accidentally engage in EM. Dhole, Manchiraju, and Suki (2016) show that managers understand the risks of EM; managers with large 
pensions, or inside debt, are less likely to use EM. They don't want to risk losing a large pension if the company fails. All managers need to do to prevent EM is to document the long-term reason for changing the status quo. Why was the change made? How is the decision not EM? These are not difficult questions. What is difficult is justifying EM, because there is often no economic reason to do it.

Abandoning EM means leaders give up the tools to meet short-term goals. Often, the company is within just a penny or two of meeting expected EPS. Because EPS is rounded up, often a small amount of EM will make the first extra penny. Other pennies demand full price. Executives that give up power to change earnings are at the mercy of the market reacting negatively to earnings surprised. Missing an EPS target can punish the stock price. Sometimes missing earnings by just a penny or two can lead to dramatic stock price movements. However, it says a lot about the ethics of company leaders that say no to EM; a strong ethical culture is a powerful weapon to fight EM (Malhotra, 2013). It means not doing something that will achieve a current earnings target in favor of sustainable earnings. There is evidence that markets discount the effects of EM in pricing, so again, the practice only benefits a few insiders (Goel, 2017). Abandoning EM might be painful for corporate stakeholders at first, but true financial statements are worth it.

There are consequences for failing to achieve targets, but companies with strong and ethical leadership and reasonable expectations will not set executives and managers up for failure. It is important to understand that when company insiders use EM to show success, it is really a failure. EM creates an illusion. If the Board and the stockholders approve an EM policy and it is disclosed in the annual report, the negative effects of EM can be reduced or eliminated. Investors can decide if they are comfortable with the policy and make an informed decision.

\section{Realistic Performance Targets}

If the Board of Directors ignores the problem, EM can occur when executives need to boost earnings to meet the public's periodic earnings expectations, like those set by a FA that monitors the company and its related industry. Despite their intuition and experience, the FA forecasters rely on incomplete information. Instead of letting outsiders set targets, the Board of Directors should do it themselves. The Board has access to propriety company data on a real-time basis. They also have the resources to obtain advice from experts to set reasonable targets. The targets should challenge executives to perform, but not to such an extent that they must rely on EM. Pressure, or incentive, is the pinnacle of the Fraud Triangle model (Cressy, 1973; see Appendix D). Executives should not be pressured too much because they possess vast opportunities to cook the books to meet targets or order subordinates to do so. Separating the role of CEO and Chairman will also increase accounting transparency (Yasser, \& Al Mamun, 2016). Boards need to be vigilant in corporate governance and fight abusive EM.

Another benefit to the Board setting earnings targets is that they can make targets dynamic; they can quickly raise, or lower targets as internal and external circumstances change. For example, if a major macroeconomic event occurred, executives' performance targets could be adjusted to exclude the effect of issues beyond their control. This can work both ways for executives. For example, if some event outside of the control of executives was beneficial to earnings, performance targets could be raised. This action would prevent executives from being lazy or setting up a cookie jar for future use. If some event outside of the control of executives was averse to earnings, targets could be lowered. This action should help prevent the desperate use of AEM and REM.

Holding people responsible for things outside of their control is poor leadership and an invitation for EM. Appendix C contains a simple framework for dynamic performance targets. The Board should pronounce judgment on their executives' performances because only they have all the information to make the right decisions. They can consider FAs consensus sales and EPS targets, in their calculations. However, the Board should make the final call. Sometimes Board members might not always be the best defense against reckless EM usage. If a Board member is either increasing or decreasing his equity position in the short term, he should recuse himself from approving some executive policies to avoid a conflict of interest. 


\section{FIGURE 6 \\ SETTING THE RIGHT PRESSURES \& INCENTIVES}

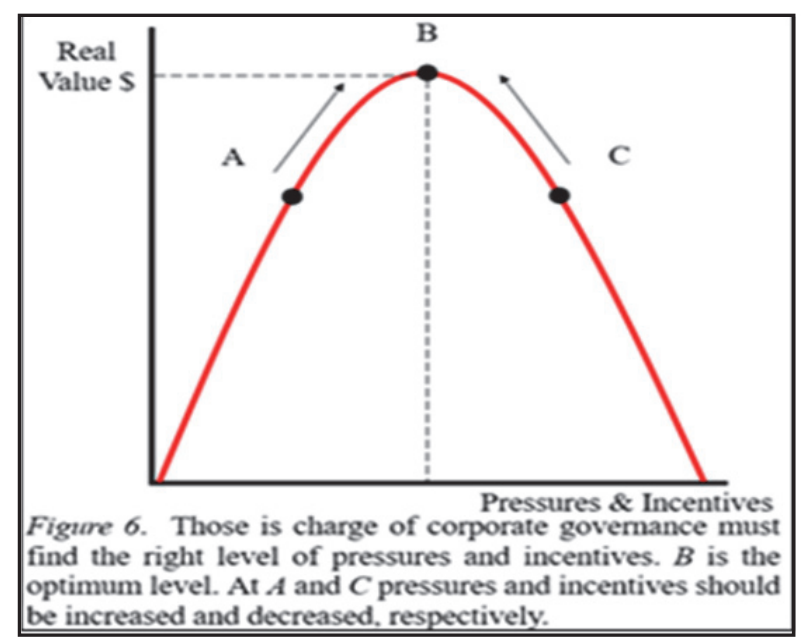

\section{Greater Involvement by Audit Committee and Internal Auditors}

The Audit Committee should play an active role in overseeing accounting policies. They can assign internal auditors to develop clear guidance for executives. Not every business decision should require notification to and approval from a higher authority in the company, but some level of materiality should be established. This is simply a common-sense internal control. No one should be able to cut spending on $\mathrm{R} \& \mathrm{D}$ or another expense deemed discretionary without some approval and coordination with strategysetters. Those cuts might undermine the company's integrated marketing plan or undermine innovation and new product development. Changes in corporate strategy can also involve very sensitive proprietary information and trade secrets. However, the company should be able to rely on the Audit Committee and internal auditors to protect this information.

Since the Sarbanes-Oxley Act of 2002, managers must establish and assess their internal controls. Having a clear policy limiting EM, training managers in the policy, and enforcing the policy sends a strong signal throughout the company. COSO (2013) provides a framework for internal controls, including control environment, risk assessment, control activities, information and communication, and monitoring. EM can be expensive. It exposes the company to huge legal liabilities. EM, especially REM, contributes to auditor resignations and higher audit fees (Greiner, Kohlbeck, \& Smith, 2017). Executives should inform the Audit Committee about material accounting policy changes before they occur. Any policy changes made immediately before or after earnings expectation are announced should be explained and approved. With the internal audit department as a resource and independence required by SOX, the Audit Committee should prevent, detect and correct abusive EM (Abdullahi, \& Ibrahim, 2017). See Appendix A for a definition and identification of EM and Appendix B for an example of internal controls over EM. Saying no to EM will reduce the cost and extent of audits and reap untold benefits from higher earnings quality. There is simply no reason for companies to allow unrestrained EM unless they want to maintain the option to cook the books. 


\section{FIGURE 7 \\ THE EM CODIFICATION BENEFIT}

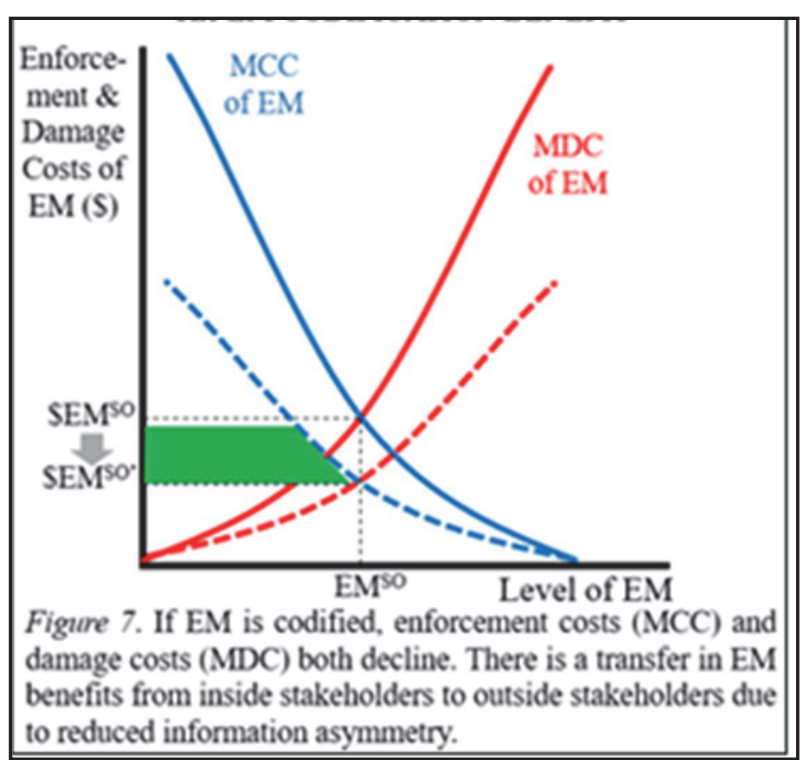

\section{The Need to Have Imagination and Creativity}

Leaders of organizations must wage a constant war to prevent apathy and promote innovation. Government bureaucrats are not known for imagination and creativity (9/11 Report, 2004). The Securities and Exchange Commission needs to acquire imagination and creativity to fulfill its mission to protect investors. With a generous annual budget, the SEC can recruit talented people, provide them powerful tools, and employ the police powers of government. Does the SEC have informants in powerful institutions and corporations? Some CFOs and CEO's might share details of EM if offered protection for cooperating. The SEC could ask a judge to authorize some wire-taps. If there were probable cause, it would be interesting to know what those chief executives talk about immediately before and after those earnings targets are announced every quarter on Wall Street. Many of them are discussing EM, or worse. The peer-reviewed journals contain undeniable evidence of this fact. With a little creativity and imagination, the SEC could do a better job. Under the watchful eye of its Inspector General, the SEC can and should find out is really going on without undermining anyone's Constitutional rights.

The SEC can offer an amnesty program for EM users. For example, in the past, many Americans have had illegal overseas bank accounts. In 2009 Swiss bank USB was exposed for defrauding the U.S. Government; USB was not alone (Dorot, 2014). That summer, the Swiss agreed to lift their famous cloak of bank secrecy and fast-tracked cooperation with the U.S. Internal Revenue Service (U.S. \& Switzerland, 2009). The IRS then launched several versions of an amnesty program for foreign bank account holders from 2009 to 2018; the IRS OVDP program brought over 56,000 people out of the shadows and raised over $\$ 11$ Billion in taxes and penalties (IRS, 2018). Simply allowing violators to come forward to avoid criminal penalties can work. There are many CEO's and CFO's that would like to stop the EM; they just want to come clean, take a big bath, and stop worrying about Federal agents breaking down the door. To be fair, the SEC is not alone. Accountants, financial analysts, business leaders, investors, lenders, and other regulators are guilty of looking the other way. Maybe it is time for everyone to take a big bath and start over. 


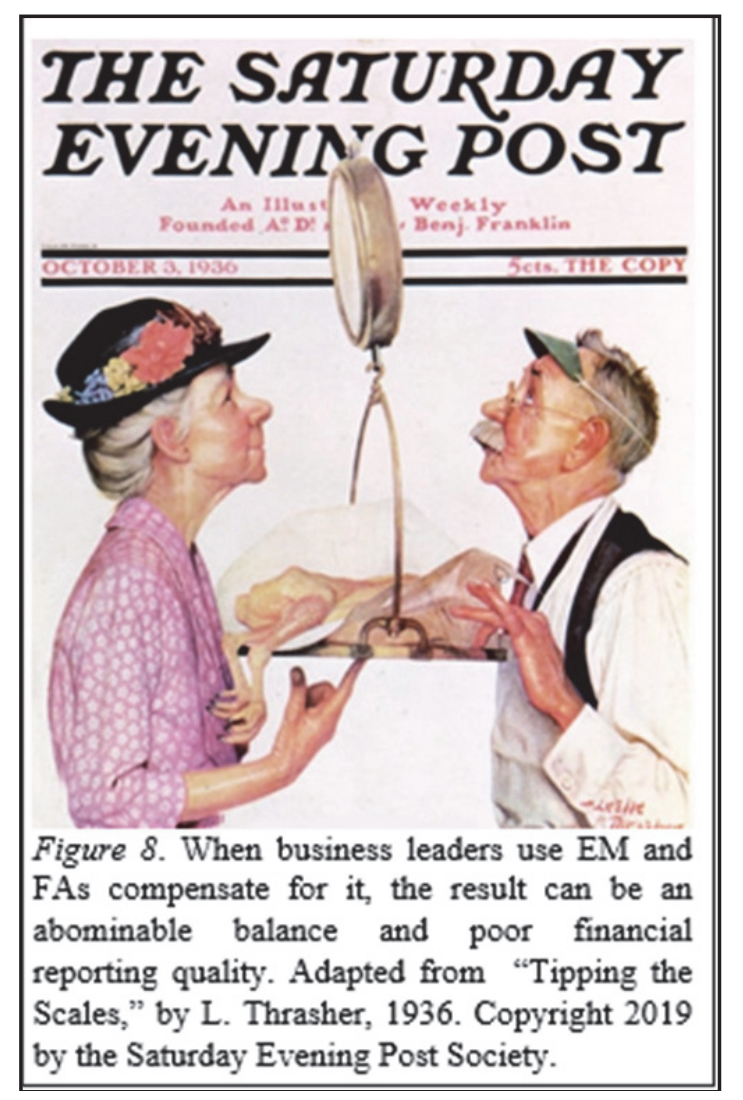

Perhaps it is time to acknowledge that EM is a permanent part of our financial system. If that is the case, the SEC can instruct the Financial Accounting Standards Board (FASB) to initiate a study to formally codify some EM into GAAP. FASB for years has allowed companies to smooth out large gains and losses in their huge pension funds (Keiso, Weygandt, \& Warfield, 2016). Without the smoothing, market fluctuations would create unexpected gains and losses in comprehensive income; this might cause confusion. Maybe guidance for other smoothing is needed. Bringing EM out of the shadows and into the rules, principles, and reporting will lower EM costs from information asymmetry. The literature on EM indicates that FAs and other outsiders are adjusting earnings expectations and pricing to account for EM. This can create an EM-Cycle in which business leaders engage in EM to meet aggressive targets from FAs that are compensating for the EM. Eliminating EM or preventing its abuse will improve the accuracy of signaling, promote financial transparency, prevent restatements, and lower agency costs (Chandren, 2016). Expensive regulatory enforcement costs would also diminish. Auditors and regulators could focus on other issues. Maybe the financial world can live with a little EM, but how much? This is a wide-open area for new research.

\section{CONCLUSION}

EM is a pervasive problem in our financial system, but it has been tolerated for decades. Principals and professionals that have a duty to demand accuracy, sincerity, and transparency in financial reporting have become too cozy with the status quo. Now is the time for financial analysts, corporate governance, investors, lenders, auditors, and government regulators to demand that those in charge of corporate policy and strategy put a quick end to abusive EM. EM has never been complicated. It has always been about a 
few winners and a lot more losers. Which company will be the first to declare its commitment to end EM? It is time to have a discussion and time for leaders to take a stand.

This paper adds value to the professional and academic discussion of EM. While most of the assertions and strategies presented in the paper are based on unscientific observation and opinion, each might offer an opportunity for future research. Perhaps researchers can find a way to prove some assertions with scholarly methods or offer better ones for study. Maybe some business leaders will reveal the truth, either anonymously or with protection from civil and criminal penalties. It is possible that someday EM can be brought out into the open and even codified in GAAP and IFRS. Talking more about EM will only bring more data, more understanding, more ideas, and better strategies to eliminate the practice or render it harmless.

\section{REFERENCES}

Abdullahi, L. B., \& Ibrahim, S. O. (2017). An evaluation of factors determining earnings management in Nigeria. Amity Global Business Review, 1233-1245.

Akisik, O., \& Gal, G. (2017). The impact of corporate social responsibility and internal controls on stakeholders' view of the firm and financial performance. Sustainability Accounting, Management and Policy Journal, 8(3), 246-280. Retrieved from https://libweb.uwlax.edu/login?url=https://search-proquestcom.libweb.uwlax.edu/docview/1918810879?accountid=9435

Al-Attar, A. M., \& Maali, B. M. (2017). The effect of earnings quality on the predictability of accruals and cash flow models in forecasting future cash flows. Journal of Developing Areas, 51(2), 45 58. Retrieved from https://libweb.uwlax.edu/login?url=https://search.ebscohost.com/login.aspx?direct=true\&AuthTy

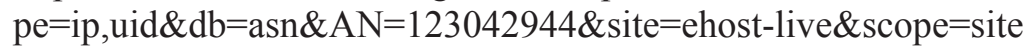

Anderson, E. (2015, November 12). Natural resource and environmental economics. Lecture presented at Old Dominion University, Norfolk, Virginia.

Antwi, S. K., \& Hamza, K. (2015). Qualitative and quantitative research paradigms in business research: A philosophical reflection. European Journal of Business \& Management, 7(3), 217-225. Retrieved from www.ejbss.org

Bendickson, J., Muldoon, J., Liguori, E. W., \& Davis, P. E. (2016). Agency theory: Background and epistemology. Journal of Management History, 22(4), 437-449. https://doiorg.ezp.waldenulibrary.org/10.1108/JMH-06-2016-0028

Capkun, V., Collins, D., \& Jeanjean, T. (2016). The effect of IAS/IRFS adoption on earnings management (smoothing): A closer look at competing explanations. Journal of Accounting and Public Policy, 35(4), 352-394. doi:10.1016/j.jaccpubpol.2016.04.002

Cardos, I. R. (2014). New trends in budgeting - a literature review. SEA: Practical Application of Science, 2(2), 483-489. Retrieved from https://libweb.uwlax.edu/login?url=https://search.ebscohost.com/login.aspx?direct=true\&AuthTy

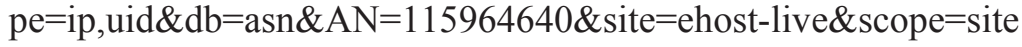

Caylor, M. L. (2010). Strategic revenue recognition to achieve earnings benchmarks. Journal of Accounting and Public Policy, 29(1), 82-95. doi:10.1016/j.jaccpubpol.2009.10.008

Caylor, M. L., \& Chambers, D. J. (2015). Reaching Into the Cookie Jar? Why Conservative Accounting Is Sometimes a Problem. Journal Of Corporate Accounting \& Finance (Wiley), 26(5), 73-77. doi: $10.1002 /$ jcaf.22066

Caylor, M. L., Christensen, T. E., Johnson, P. M., \& Lopez, T. J. (2015). Analysts' and investors' reactions to consistent earnings signals. Journal Of Business Finance \& Accounting, 42(9/10), 1041-1074. doi:10.1111/jbfa.12163

Chandren, S. (2016). Review on the double side of earnings management. Pertanika Journal of Social Sciences \& Humanities, 24(4), 1253-1265. 
Cheng, Q., Lee, J., \& Shevlin, T. (2016). Internal governance and real earnings management. Accounting Review, 91(4), 1051-1085. doi:10.2308/accr-51275

Cohen, D. A., \& Zarowin, P. (2010). Accrual-based and real earnings management activities around seasoned equity offerings. Journal of Accounting and Economics, 50(1), 2-19. doi:10.1016/j.jacceco.2010.01.002

Cohen, J., Ding, Y., Lesage, C., \& Stolowy, H. (2017). Media bias and the persistence of the expectation gap: An analysis of press articles on corporate fraud. Journal of Business Ethics, 144(3), 637-659. doi:10.1007/s10551-015-2851-6

Collins, D. W., Pungaliya, R. S., \& Vijh, A. M. (2017). The effects of firm growth and model specification choices on tests of earnings management in quarterly settings. Accounting Review, 92(2), 69-100. doi:http://dx.doi.org/10.2308/accr-51551

Commerford, B. P., Hermanson, D. R., Houston, R. W., \& Peters, M. F. (2016). Real earnings management: A threat to auditor comfort?. Auditing: A Journal Of Practice \& Theory, 35(4), 3956. doi:10.2308/ajpt-51405

COSO. (2013). Internal control - integrated framework executive summary. Committee of Sponsoring Organizations of the Treadway Commission (COSO). Retrieved from https://na.theiia.org/standards-guidance/topics/Documents/Executive_Summary.pdf

Cressey, D. R. (1973). Other People's Money. Montclair: Patterson Smith.

Currim, I. S., Lim, J., \& Zhang, Y. (2018). Effect of analysts' earnings pressure on marketing spending and stock market performance. Journal of the Academy of Marketing Science, 46(3), 431-452. doi:0.1007/s11747-017-0540-y

Dhaliwal, D. S., Gleason, C. A., \& Mills, L. F. (2004). Last-chance earnings management: Using the tax expense to meet analysts' forecasts. Contemporary Accounting Research, 21(2), 431-459.

Dhole, S., Manchiraju, H., \& Suk, I. (2016). CEO inside debt and earnings management. Journal Of Accounting, Auditing \& Finance, 31(4), 515-550. doi:10.1177/0148558X15596907

Dorot, D. Z. (2014). Offshore account compliance: The evolution of a revolution. Florida Bar Journal, 88(10), 36-41. Retrieved from https://libweb.uwlax.edu/login?url=https://search.ebscohost.com/login.aspx?direct=true\&AuthTy

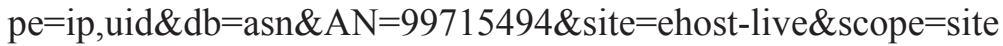

Ekimoff, C. (2014). Expectations smoothing: 'cookie jar' reserves for your career. Fraud Magazine, 29(6). Retrieved from http://www.fraud-magazine.com/article.aspx?id=4294986545

Ettredge, M., Scholz, S, Smith, K. R., \& Sun, L. (2010). How do restatements begin? Evidence of earnings management preceding restated financial reports. Journal of Business Finance \& Accounting, 37(3-4), 332-355. doi:10.1111/j.1468-5957.2010.02199.x

Evans, M. E., Houston, R. W., Peters, M. F., \& Pratt, J. H. (2015). Reporting regulatory environments and earnings management: U.S. and non-U.S. firms using U.S. GAAP or IFRS. The Accounting Review, 90(5), 1969-1994. doi:10.2308/accr-51008

Fang, V. W., \& Fu, R. (2018). The bright side of earnings management. Retrieved from https://papers.ssrn.com/sol3/papers.cfm?abstract_id $=3224800$

Fedyk, T. (2017). Refining financial analysts' forecasts by predicting earnings forecast errors. International Journal Of Accounting \& Information Management, 36(3), 256-272. doi:10.1108/IJAIM-06-2016-0065

Feres de Almeida, J. E., Neto, A. S., Furieri Bastianello, R., \& Zandomenigue Moneque, E. (2012). Effects of income smoothing practices on the conservatism of public companies listed on the BM\&FBOVESPA. Revista Contabilidade \& Finanças - USP, 23(58), 65-75. Retrieved from https://libweb.uwlax.edu/login?url=https://search.ebscohost.com/login.aspx?direct=true\&AuthTy

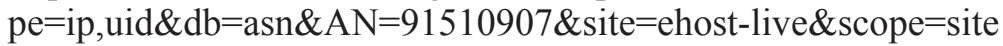

Filzen, J. J., \& Peterson, K. (2015). Financial statement complexity and meeting analysts' expectations. Contemporary Accounting Research, 32(4), 1560-1594. doi:10.1111/1911-3846.1213

Financial Accounting Standards Board. (2018a). ASC 235-10-50-1. Retrieved from https://asc.fasb.org Financial Accounting Standards Board. (2018b). ASC 235-10-50-3. Retrieved from https://asc.fasb.org 
Goel, S. (2017). Earnings management detection over earnings cycles: The financial intelligence in Indian corporate. Journal of Money Laundering Control, 20(2), 116-129. doi:10.1108/JMLC-06-20160023

Grabińska, B., \& Grabiński, K. (2017). The Impact of R\&D expenditures on earnings management. Argumenta Oeconomica Cracoviensia, (17), 53-72. doi:/10.15678/AOC.2017.1704

Greiner, A., Kohlbeck, M. J., \& Smith, T. J. (2017). The Relationship between Aggressive Real Earnings Management and Current and Future Audit Fees. Auditing: A Journal Of Practice \& Theory, 36(1), 85-107. doi:10.2308/ajpt-51516

Hancock, J. T., Curry, L. E., Goorha, S., \& Woodworth, M. (2008). On lying and being lied to: A linguistic analysis of deception in computer-mediated communication. Discourse Processes, 45(1). doi:10.1080/01638530701739181

Healy, P. M. (1985). The effect of bonus schemes on accounting decisions. Journal of Accounting and Economics, 7, 85-107. Retrieved from https://econ.au.dk/fileadmin/Economics_Business/Education/Summer_University_2012/6308_Ad vanced_Financial_Accounting/Advanced_Financial_Accounting/4/Healy_JAE_1985.pdf

$\mathrm{Hu}, \mathrm{H}$. (2019, March). Real earnings management and the trade-off among earnings management alternatives in innovation-intensive companies. Paper presented at the conference of the Southwest American Accounting Association, Houston.

Hu, N., Hao, Q., Liu, L., \& Yao, L. J. (2015). Managerial tenure and earnings management. International Journal of Accounting \& Information Management, 23(1), 42-59. doi.org/10.1108/IJAIM-042014-0025

Hu, N., Huang, R., Li, X., \& Liu, L. (2017). The impact of CEOs' accounting backgrounds on earnings management and conservatism. Journal of Centrum Cathedra, 10(1), 4-24. doi.org/10.1108/JCC10-2016-0016

Jiang, X., \& Yang, M. (2016). Properties of optimal accounting rules in a signaling game. Journal of Accounting and Economics, 63(3), 499-512. doi:10.1016/j.jacceco.2016.07.004

Jordan, C. E., \& Clark, S. J. (2015). Do new CEOs practice big bath earnings management via goodwill impairments?. Journal Of Accounting \& Finance, 15(7), 11-21.

Kamarudina, K. A, \& Ismailb, W. A. W. (2014). The risk of earnings quality impairment Procedia Social and Behavioral Sciences, 145, 226 - 236. doi:10.1016/j.sbspro.2014.06.030

Kaufinger, G. G. (2015). The use of gift card breakages as an earnings management tool. International Journal Of Business, Accounting, \& Finance, 9(2), 31-43.

Kieso, D. E., Weygandt, J. J., \& Warfield, T. D. (2016). Intermediate accounting (16 ed.). Hoboken, NJ: Wiley.

Legoria, J., Melendrez, K., \& Reynolds, J. (2013). Qualitative audit materiality and earnings management. Review Of Accounting Studies, 18(2), 414-442. doi:10.1007/s11142-012-9218-3

Li, T., Luo, M., \& Ng, D. (2014). Earnings management and listing regulations in China. China Finance Review International, 4(2), 24-152. https://doi.org/10.1108/CFRI-02-2014-0005

Li, V. (2016). Do false financial statements distort peer firms' decisions? Accounting Review, 91(1), 251-278. doi:10.2308/accr-51096

Liu, Y., Wei, Z., \& Xie, F. (2016). CFO gender and earnings management: Evidence from China. Review Of Quantitative Finance \& Accounting, 46(4), 881-905. doi:10.1007/s11156-014-0490-0

Lo, K., Ramos, F., \& Rago, R. (2016). Earnings management and annual report readability. Journal of Accounting and Economics, 63(1). doi:10.1016/j.jacceco.2016.09.002

Malhotra, A. K. (2013). Curbing creative accounting: role \& effectiveness of ethics. International Journal Of Finance \& Policy Analysis, 5(2), 15-26.

Mellado-Cid, C., Jory, S. R., \& Ngo, T. (2017). Real earnings management activities prior to bond issuance. Business Research Quarterly, 20(3), 164-177. https://doiorg.libweb.uwlax.edu/10.1016/j.brq.2017.04.004 
Medeiros Cupertino, C., Lopo Martinez, A., \& da Costa Jr., N. C. A. (2016). Consequences for future return with earnings management through real operating activities. Revista Contabilidade \& Finanças - USP, 27(71), 232-242. doi:10.1590/1808-057x201602520

Mindak, M. P., Sen, P. K., \& Stephan, J. (2016). Beating threshold targets with earnings management. Review of Accounting and Finance, 15(2), 198-221. doi:10.1108/RAF-04-2015-0057

Naidu, D., \& Patel, A. (2013). A Comparison of qualitative and quantitative methods of detecting earnings management: Evidence from two Fijian private and two Fijian state-owned entities. Australasian Accounting Business \& Finance Journal, 7(1), 79-98.

National Commission On Terrorist Attacks Upon the Unites States. (2004). The 9/11 commission report. National Commission On Terrorist Attacks Upon the Unites States. Retrieved from https://www.9-11 commission.gov/report/

Nketia, J. (2019, March). Earnings management in United States private firms. Paper presented at the conference of the Southwest American Accounting Association, Houston.

Paiva, I. S., Lourenço, I. C., \& Branco, M. C. (2016). Earnings management in family firms: current state of knowledge and opportunities for future research. Review Of Accounting \& Finance, 15(1), 85100. doi:10.1108/RAF-06-2014-0065

Palliam, R. \& Shalhoub, Z. (2003). The phenomenology of earnings management within the confines of agency theory. International Journal of Value-Based Management, 16(1), 77-88. doi:10.1023/A:1021979228682

Peng, W., Lei, G., \& Tingting, G. (2015). Business strategy, market competition and earnings management: Evidence from China. Chinese Management Studies, 9(3), 401-424. doi.org/10.1108/CMS-12-2014-0225

Peng, W., Lei G., \& Xiao, L. (2016). Does the reputation mechanism of media coverage affect earnings management?: Evidence from China. Chinese Management Studies, 10(4), 627-656. doi.org/10.1108/CMS-08-2016-0177

Pepper, A., \& Gore, J. (2015). Behavioral Agency Theory: New Foundations for Theorizing About Executive Compensation. Journal Of Management, 41(4), 1045-1068. doi:10.1177/0149206312461054

Qaiser, R. Y., \& Abdullah, A. (2016). The relationship between board leadership structure and earnings management in Asia-Pacific. Accounting Research Journal, 29(4), 413-428. doi: 10.1108/ARJ06-2015-0080

Qian, W., Gaixia, L., Jiayi, X., \& Qun, L. (2017). Factors influencing the accuracy of financial analysts' earnings forecast--empirical data from strategic emerging industries. Revista De La Facultad De Ingeniería U.C.V., (7), 265-276. Retrieved from http://revistadelafacultaddeingenieria.com/index.php/ingenieria/article/download/1851/1811

Radu, M., \& Giju, G. C. (2015). The flexible budget-basic tool of the management control in the economic entities. Scientific Bulletin - Economic Sciences / Buletin Stiintific - Seria Stiinte Economice, 14(1), 3-10. Retrieved from

https://libweb.uwlax.edu/login?url=https://search.ebscohost.com/login.aspx?direct=true\&AuthTy

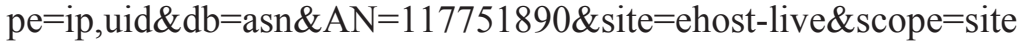

Trejo-Pech, C. J. O, Weldon, R. N., \& Gunderson, M. A. (2015). Earnings management through specific accruals and discretionary expenses: Evidence from U.S. agribusiness firms. Canadian Journal of Agricultural Economics, 64(1), 89-118. doi:10.1111/cjag.12063

United States and Switzerland Agree on Access to Swiss Bank Information. (2009). The American Journal of International Law, 103(4), 748-750. Retrieved from http://www.jstor.org/stable/20617048

U.S. Internal Revenue Service. (2018). IRS: Offshore voluntary compliance program to end sept. 28. Internal Revenue Service News Releases (IR-2018-176, Sept. 4). Retrieved from https://www.irs.gov/newsroom/irs-offshore-voluntary-compliance-program-to-end-sept-28

Vladu, A. B. (2015). Managerial preferences between accrual-based versus real earnings management. Hyperion International Journal of Econophysics \& New Economy, 8(2), 409-417. Retrieved from

72 Journal of Accounting and Finance Vol. 19(4) 2019 
https://libweb.uwlax.edu/login?url=https://search.ebscohost.com/login.aspx?direct=true\&AuthTy pe $=$ ip, uid \&db=asn \&AN $=117209582 \&$ site $=$ ehost-live \&scope $=$ site

Welker, M., Ye, K., \& Zhang, N. (2017). (Un)intended consequences of a mandatory dividend payout regulation for earnings management: Evidence from a natural experiment. Journal of Accounting, Auditing \& Finance, 32(4), 510-535. doi:10.1177/0148558X16689654

Xuan, H., Siew Hong, T., \& Yinglei, Z. (2014). Tone management. Accounting Review, 89(3), 10831113. doi:http://dx.doi.org/10.2308/accr-50684

Yasser, Q. R., \& Al Mamun, A. (2016). The relationship between board leadership structure and earnings management in Asia-Pacific. Accounting Research Journal, 29(4), 413-428. doi: 10.1108/ARJ06-2015-0080

Zhu Liu, A. (2014). Can external monitoring affect corporate financial reporting and disclosure? Evidence from earnings and expectations management. Accounting Horizons, 28(3), 529-559. doi.org/10.2308/acch-50771

\section{APPENDICES}

\section{APPENDIX A \\ DEFINING AND IDENTIFYING EM}

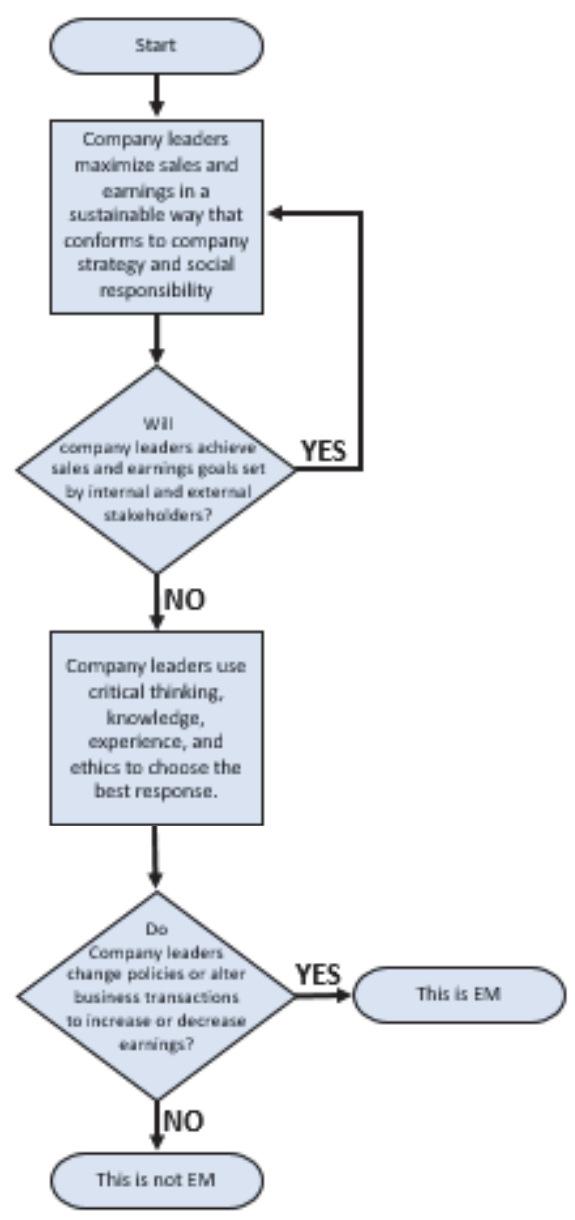


APPENDIX B

INTERNAL CONTROLS TO ELIMINATE UNAUTHORIZED OR ABUSIVE EM

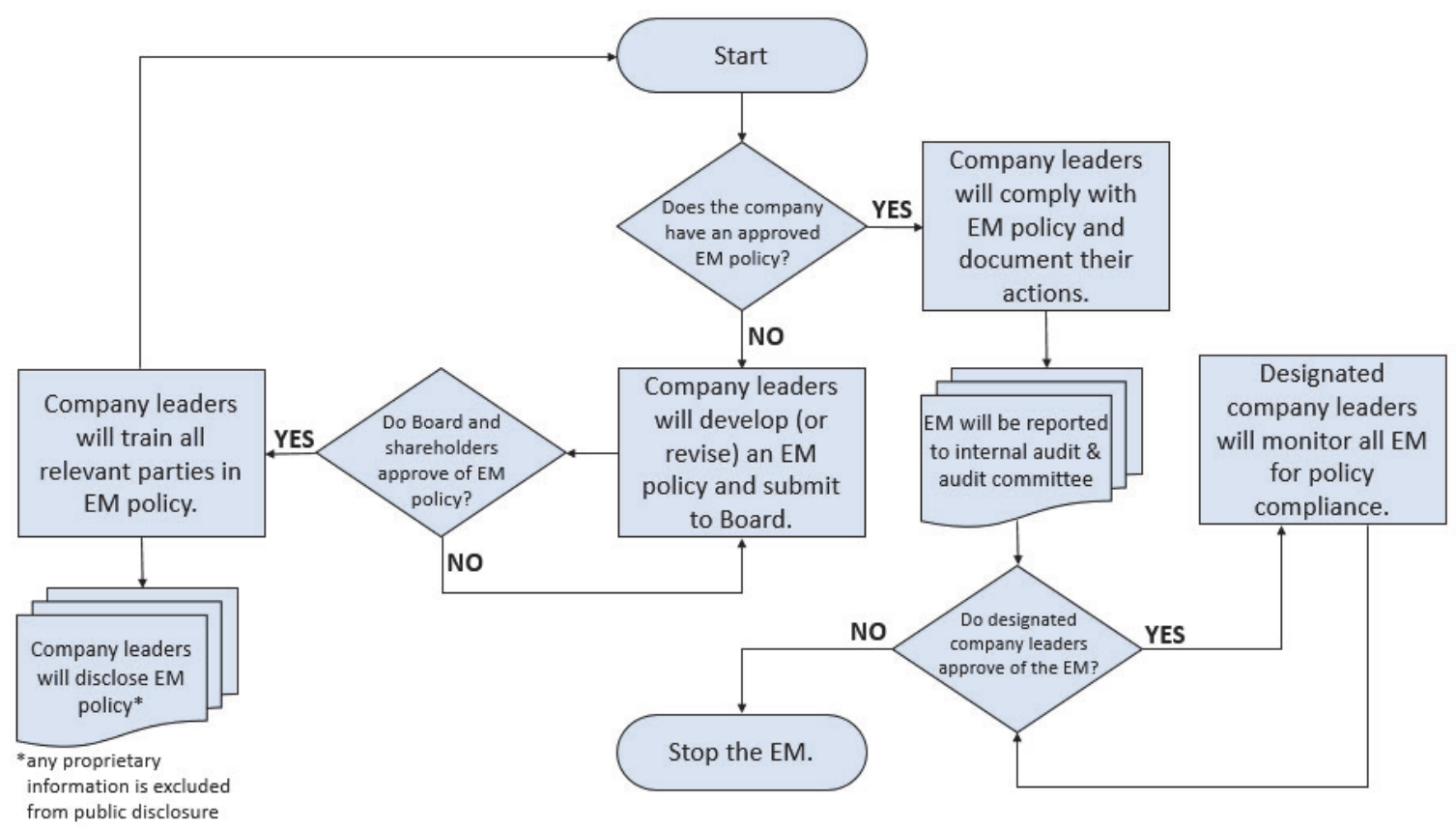

APPENDIX C

A FRAMEWORK FOR CREATING DYNAMIC PERFORMANCE TARGETS

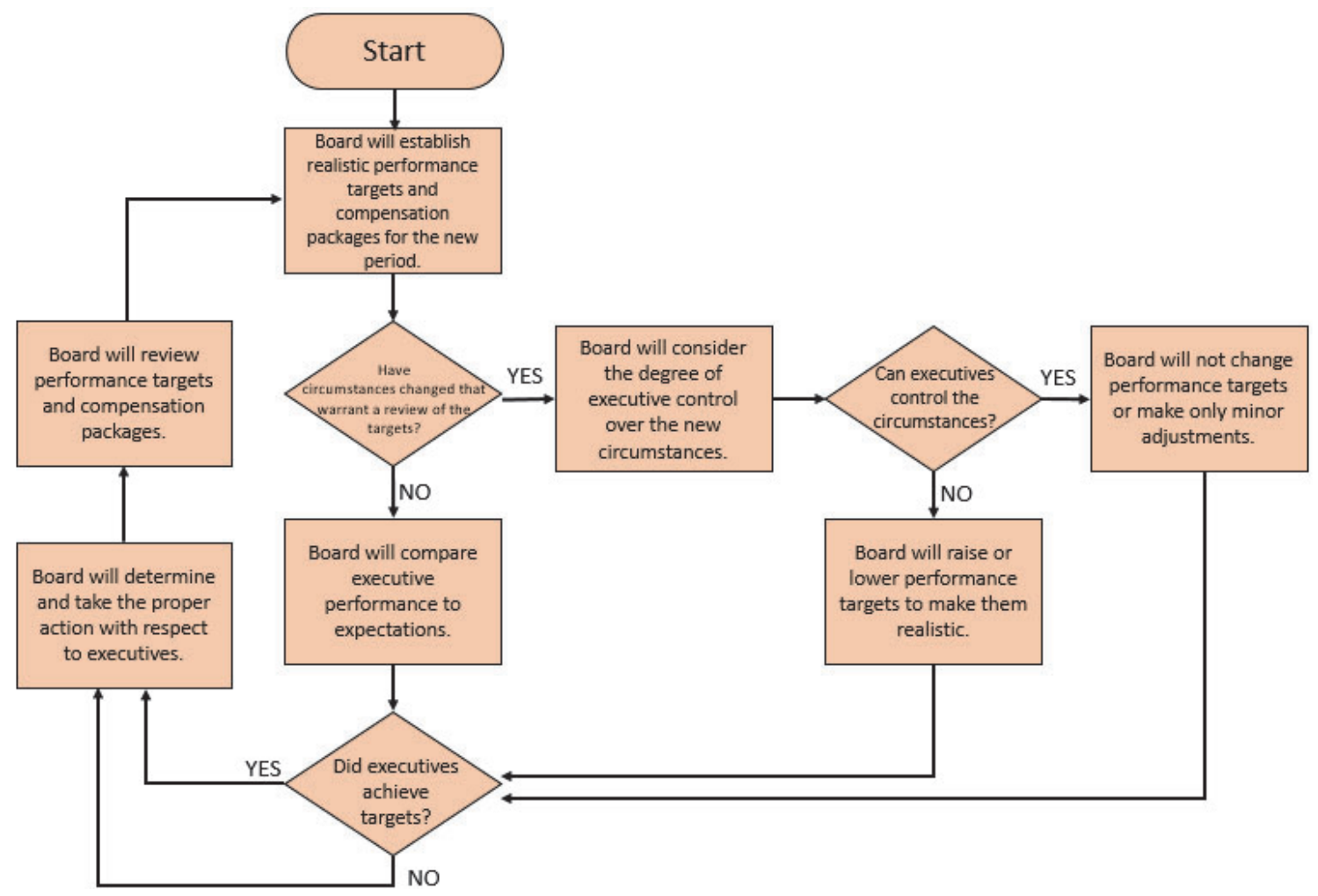

74 Journal of Accounting and Finance Vol. 19(4) 2019 


\section{APPENDIX D \\ THE FRAUD TRIANGLE}

Fraud is an intentional act of misappropriation assets or misstatement in the financial statements. Cressey (1973) first proposed a triad of elements that can be found in every case of fraud. The three elements are pressure and incentive, opportunity, and rationalization. It is important for leaders to understand the fraud triangle; they need to promote a high level of ethics and ensure that subordinates understand that fraud is never the way to advance their interests or those of the organization. If an organization does not over-pressure or incentivize, provide easy opportunities, and give cover for fraud, then fraud is much less likely to occur.

\section{Pressure and Incentives}

Every person in an organization faces financial pressure and is motivated by financial incentives. Leaders should find the right level of pressures and incentives to motivate subordinates. However, too much will encourage fraud. Financial pressures can come from both inside and outside of the organization. Forms can include very basic human needs, such as: Filling the tank with gas, buying diapers or baby formula, or paying doctor bills. A person facing this kind of pressure might cut back on non-essential spending, borrow from family and friends, or get a part-time job. They might also steal from the petty cash box, steal inventory, or commit some other fraud. What if an executive had only $\$ 0.05$ EPS between her and \$10 Million in performance bonuses or expiring out-of-the-month stock options? No one could blame her for one little journal entry. Pressure and incentives are powerful forces in peoples' lives; each can lead good people to do bad things.

\section{FIGURE 9}

\section{THE FRAUD TRIANGLE}

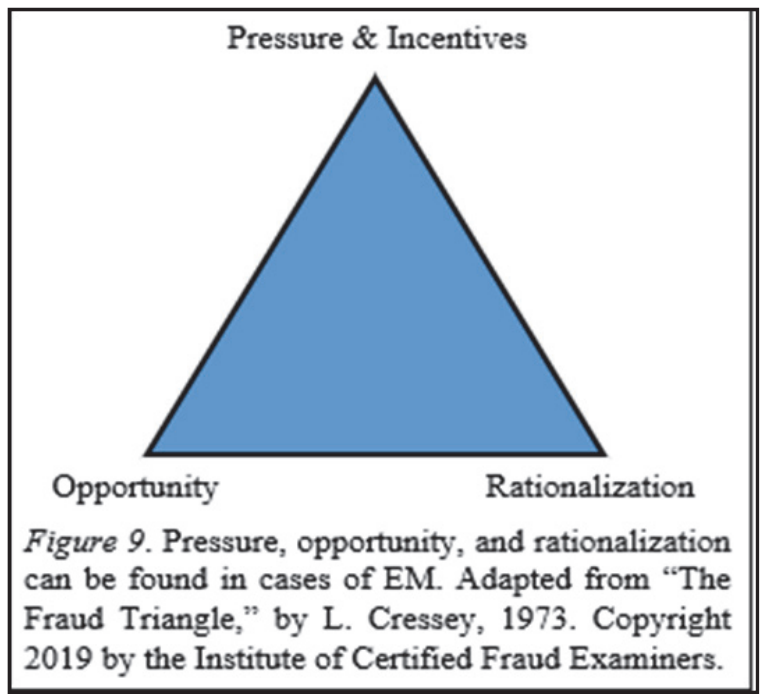

Leaders cannot control most of the pressures their employees face outside the organization, but they can make sure that organizational pressures are not the primary cause of fraud. Setting reasonable performance goals is a good policy. People should not be punished for failures due to macroeconomic issues that are beyond their control; likewise, they should not be rewarded for achievements that were not the result of their performance. Leaders can set a strong ethical tone, pay employees good salaries, provide financial training, and establish an assistance fund for employees' emergencies. If leaders show subordinates that there are legal and ethical pathways to relieve pressures, that would reduce the likelihood of fraud. 


\section{Opportunity}

Fraud can only occur if there is an opportunity, but there is almost always an opportunity for a determined fraudster. This is because the cost of protecting an organization's assets completely is simply too expensive; organizations must accept some degree of risk of fraud. Many employees have access to cash, inventory, and other assets. Others have access to the accounting system and can make journal entries, enter data, or delete data. For example, a clerk might go into the payroll system and give themselves a nice raise or put their spouse on the payroll, too. Smart people figure out ways to get around the internal controls to steal assets. Some of them even figure out ways to cover up their crimes. If there is an opportunity, fraud can occur.

The worst persons to over-pressure or over-incentivize are company leaders. They have the power to direct subordinates, to change policies, and often have unrestricted access to assets and systems. Effective internal controls and a strong, ethical tone are the best defense against fraud. Having a code of ethics is meaningless unless leaders follow it and insist others do as well. Enron had a strong code of ethics and Lay (2000) promulgated it to the entire company. However, the culture of the company was greed and fraud; countless stakeholders were hurt by Enron's collapse.

\section{Rationalization}

Few fraudsters see themselves as such. Everyone that commits fraud will attempt to rationalize their actions. In the case of Enron, everyone was doing it. Other justifications for fraud include: I will return it someday, the company doesn't pay me enough for the work I do, or the company won't miss it. If employees are disgruntled, it is easier for them to justify stealing from the company. Paying respectable salaries, maintaining a safe and professional workplace, and treating people with dignity are sound leadership practices; each will go a long way toward discouraging people from committing fraud. People will not commit fraud if they cannot justify or rationalize it. 